\title{
Kostruksi Makna Tradisi Walimatul ‘Ursy bagi Masyarakat Barumanis Kabupaten Rejang Lebong, Bengkulu, Indonesia
}

\author{
Sutarto Sutarto ${ }^{1 *}$, Idi Warsah ${ }^{2}$, Ngadri Ngadri ${ }^{3}$ \\ 1 Institut Agama Islam Negeri (IAIN) Curup, Bengkulu, Indonesia; sutarto@iaincurup.ac.id \\ 2 Institut Agama Islam Negeri (IAIN) Curup, Bengkulu, Indonesia; idiwarsah@iaincurup.ac.id \\ 3 Institut Agama Islam Negeri (IAIN) Curup, Bengkulu, Indonesia; ngadri1969@gmail.com \\ * Correspondence
}

Received: 2020-10-01; Accepted: 2021-03-16; Published: 2021-05-12.

\begin{abstract}
The tradition of the feast of marriage or walimatul 'ursy is a Javanese tradition that can work together to motivate and become the glue of multicultural unity for the people of Barumanis village, Rejang Lebong Regency. This study aims to find and explain the meaning and experience of the Barumanis village community in carrying out the walimatul 'ursy tradition. This research is qualitative research based on a constructivist paradigm, using a phenomenological approach. Data collection techniques through in-depth interviews, participatory observation, and data documentation. The results of the study found that there are a common understanding and belief of the community in interpreting the feast of marriage, making the wedding feast can be the glue of unity in a multicultural society. The tradition of the feast of marriage has a positive value for people's lives, therefore it is preserved by increasing community commitment and awareness, being passed down from generation to generation, and the existence of unwritten social sanctions.
\end{abstract}

Keywords: Experience; marriage; meaning construction; tradition; walimatul 'ursy.

\begin{abstract}
Abstrak: Tradisi kenduri kawin atau walimatul 'ursy merupakan tradisi Jawa yang mampu bersinergi sehingga memotivasi dan menjadi perekat kesatuan multikultural bagi masyarakat desa Barumanis Kabupaten Rejang Lebong. Kajian ini bertujuan untuk menemukan dan menjelaskan makna serta pengalaman masyarakat desa Barumanis dalam melakukan tradisi walimatul 'ursy. Penelitian ini merupakan penelitian kualitatif berdasarkan paradigma konstruktivis, menggunakan pendekatan fenomenologi. Teknik pengumpulan data melalui wawancara mendalam, pengamatan partisipatif, dan dokumentasi data. Hasil penelitian menemukan bahwa adanya kesamaan pemahaman dan keyakinan masyarakat dalam memaknai kenduri kawin, menjadikan kenduri kawin dapat menjadi perekat kesatuan dalam masyarakat multikultural. Tradisi kenduri kawin memiliki nilai positif bagi kehidupan masyarakat, oleh karena itu tetap dilestarikan dengan cara meningkatkan komitmen dan kesadaran masyarakat, diwariskan secara turun-temurun dan adanya sanksi sosial secara tidak tertulis.
\end{abstract}

Kata Kunci: Konstruksi makna; Pernikahan; pengalaman; tradisi; walimatul 'ursy. 


\section{Pendahuluan}

Keragaman agama dan budaya seringkali memicu munculnya konflik, baik konflik antar kelompok, konflik antar suku maupun konflik antar agama. Tragedi Sampit di Kalimantan Tengah misalnya, yang bermula dari konflik antara kelompok etnis Dayak dan Madura, kemudian meluas menjadi konflik antar suku. Awalnya ada empat anggota keluarga Madura tewas dibunuh. Warga Madura kemudian mendatangi rumah milik suku Dayak dan meminta agar menyerahkan pelaku pembunuhan. Karena permintaannya tidak dituruti, masa marah dan membakar rumah milik suku Dayak. Awalnya insiden tersebut dapat diredam oleh pihak keamanan, namun sekelompok orang kemudian datang, lalu mengejar, membunuh dan membakar rumah milik warga Madura (Abdullah, 2014; Idi Warsah, 2017).

Konflik yang dilatarbelakangi perbedaan agama juga pernah terjadi. Konflik antara kelompok Islam dan Kristen yang terjadi di Maluku misalnya. Dalam konflik ini korban jiwa mencapai 8-9 ribu orang, 29 ribu lebih rumah terbakar, 45 masjid, 47 gereja, 719 toko, 38 gedung pemerintahan, dan 4 bank hancur, bahkan terjadi hampir sekitar 4 tahun (Jati, 2013). Konflik yang disertai dengan kekerasan terjadi kadang-kala mengatasnamakan agama, sehingga oleh sebagian orang dijadikan doktrin yang harus dilaksanakan. Konflik yang diartikan sebagai kekerasan atas nama agama merupakan sikap atau perilaku mengandung tekanan, paksaan atau kekuatan yang mengatasnamakan agama (Muqoyyidin, 2013; Warsah et al., 2019). Persoalan agama merupakan suatu hal yang sangat sensitif, sehingga konflik yang sesungguhnya bukan berawal dari masalah agama, tetapi jika sudah ditarik ke dalam wilayah agama maka akan mendapat dukungan yang sangat luar biasa dari pemeluknya (Idi Warsah, Masduki, Imron, Daheri, \& Morganna, 2019; Yusuf, 2011).

Namun, tidak semua perbedaan budaya, adat istiadat dan agama memicu terjadinya konflik sosial. Perbedaan budaya, adat istiadat dan agama justru dapat dijadikan alat untuk merekat persatuan dan kesatuan bangsa. Hal ini disebabkan karena dalam setiap budaya, adat istiadat dan agama yang ada di Indonesia memiliki pesan moral dan nilai-nilai yang harus dijunjung tinggi dalam kehidupan, harus dijaga, dilestarikan dan diwariskan dari generasi ke generasi berikutnya (Fuadi, 2020; Krismoniansyah, Warsah, Jaya, \& Abdu, 2020). Oleh karena itu, agar keberagaman budaya, adat istiadat dan agama menjadi perekat kesatuan, maka harus ada sikap saling memahami, menghormati dan toleransi antar satu budaya, adat istiadat dan agama dengan budaya, adat istiadat dan agama lainnya (Hasan, 2016; Lestari, 2019).

Geertz menjelaskan, budaya pada hakekatnya adalah semua hasil karya manusia baik secara individu maupun kelompok, memiliki makna tertentu, bersifat holistik (berbentuk fisik-material, kondisi moral, spiritual dan sebagainya), mempunyai simbol tertentu dan diwariskan, sehingga dengan cara itu manusia dapat berkomunikasi, melestarikan dan mengembangkan pengetahuan dan sikap dalam setiap kehidupan (C. Geertz, 2001). Pendapat ini menegaskan bahwa budaya pada dasarnya merupakan hasil karya manusia, baik berbentuk nilai-nilai, aktivitas manusia dan benda. Budaya yang dimiliki oleh manusia dapat berkembang seiring dengan perkembangan zaman. Di sisi lain, budaya juga dapat mempengaruhi sikap dan perilaku manusia serta diwariskan dari generasi ke generasi berikutnya melalui proses interaksi sosial (Hindaryatiningsih, 2017). Sedangkan budaya lokal pada dasarnya hasil karya manusia baik berupa nilai-nilai, aktivitas manusia atau benda dalam suatu komunitas atau etnik tertentu pada suatu daerah atau kelompok masyarakat sehingga membudaya dalam totalitas kehidupan (Nurdin, 2017).

Desa Barumanis merupakan salah satu desa yang ada di Kabupaten Rejang Lebong, Propinsi Bengkulu, masyarakatnya terdiri dari multi agama (Islam, Kristen, Hindu dan Aliran Kepercayaan), dan multi suku serta budaya (Jawa, Rejang, Minang dan Batak). Walaupun demikian, masyarakat desa Baru Manis hidup rukun, damai dan saling toleransi (Warsah et al., 2019). Keragaman tersebut disatukan oleh suatu tradisi yang bernama kenduri kawin atau walimatul 'ursy. Kenduri kawin atau walimatul 'ursy diisi dengan acara doa-doa kepada para leluhur yang dipimpin oleh pemuka adat, atau agama, diselingi dengan ceramah agama, dihadiri oleh masyarakat sekitar yang berbeda agama dan sosial budaya, kemudian diakhiri dengan makan bersama yang disediakan oleh ahli rumah. 
Tradisi kenduri kawin atau walimatul 'ursy yang dilaksanakan di desa Barumanis sangat unik, karena tradisi tersebut bukan budaya asli suku Rejang, melainkan budaya yang dibawa oleh pendatang dari Jawa. Walaupun demikian, mampu berakulturasi secara dinamis, baik dengan tradisi keagamaan maupun dengan tradisi masyarakat setempat yang berbeda budaya dan agama. Sehingga dapat bersinergi dan menjadi motivasi bagi masyarakat dalam membangun toleransi antar masyarakat yang multikultural dan multi agama untuk memperkokoh persatuan dan kesatuan.

Penelitian terkait dengan tradisi kenduri kawin atau walimatul 'ursy sudah banyak dikaji oleh penelitian terdahulu. Mahfudin dan Mafthuchin (2020) memfokuskan kajiannya pada tradisi hiburan dangdut dalam walimatul 'ursy. Hukum memberi karangan bunga pada walimatul 'ursy (Fitri, 2017). Keabsahan hukum pernikahan tanpa walimatul 'ursy (Marpi, 2020). Masih banyak penelitian lain seperti yang dilakukan oleh (Heradani, 2018), yang menfokuskan kajiannya pada aspek hukum dan (Jamali, Zain, \& Hasyim, 2016) yang mengkaji dari sudut pandang Hadis. Dari beberapa penelitian tersebut, belum ada yang mengkaji secara khusus berkaitan dengan peran tradisi kenduri kawin atau walimatul 'ursy dalam merekat kesatuan pada masyarakat multikultural.

Jika dihubungkan dengan integralitas keagamaan masyarakat, maka tradisi kenduri kawin atau walimatul 'ursy ini sangat menarik untuk dikaji lebih dalam. Hal ini mengingat pluralitas agama dan budaya khususnya di desa Barumanis merupakan fakta sosial yang tidak dapat dipungkiri. Namun, tradisi kenduri kawin atau walimatul 'ursy khususnya di desa Barumanis Kecamatan Bermani Ulu Kabupaten Rejang Lebong dilakukan di tengah-tengah masyarakat multikultural bahkan multi agama, dan berlangsung secara alami. Muncul pertanyaan mengapa tradisi kenduri kawin atau walimatul 'ursy mampu menjadi perekat kesatuan pada masyarakat multikultural? Bagaimana cara masyarakat desa Barumanis dalam melestarikan tradisi kenduri kawin atau walimatul 'ursy?

Penelitian ini merupakan penelitian kualitatif dengan menggunakan pendekatan fenomenologi. Pendekatan fenomenologi merupakan salah satu pendekatan penelitian yang berupaya mengungkapkan pengalaman seseorang atau sekelompok orang (Bauto, 2016; Liliweri, 2005). Dalam penelitian ini pendekatan fenomenologi digunakan untuk mengungkapkan pengalaman seseorang atau sekelompok orang dalam melaksanakan tradisi kenduri kawin atau walimatul 'ursy pada masyarakat multi agama dan budaya di desa Barumanis yang mampu menjadi perekat kesatuan. Sumber data dalam penelitian ini adalah tokoh adat, tokoh agama dan tokoh masyarakat yang terlibat langsung dalam pelaksanaan tradisi kenduri kawin atau kenduri walimah di desa Barumanis. Teknik pengumpulan data yang digunakan adalah wawancara tidak terstruktur, yaitu wawancara dimana peneliti tidak menggunakan pedoman wawancara rinci, melainkan hanya menggunakan pedoman secara garis terkait dengan masalah yang akan diteliti (Edi, 2016; Roulston, 2014). Hasil wawancara kemudian dianalisis dengan model analisis Miles Huberman (Miles, Huberman, \& Saldana, 2014).

\section{Budaya Lokal dan Multikultural}

Budaya pada dasarnya merupakan pola kelakuan secara umum yang terdapat dalam satu masyarakat. Budaya juga dapat diartikan sebagai segala cara hidup masyarakat tertentu, dapat juga dipandang sebagai hasil terbaik masyarakat (Fargomeli, 2014). Di sisi lain, budaya juga bermakna seluruh nilai yang telah disepakati masyarakat. Geertz menjelaskan, budaya pada hakekatnya adalah semua hasil karya manusia baik secara individu maupun kelompok, memiliki makna tertentu, bersifat holistik (berbentuk fisik-material, kondisi moral, spiritual dan sebagainya), mempunyai simbol tertentu dan diwariskan, sehingga dengan cara itu manusia dapat berkomunikasi, melestarikan dan mengembangkan pengetahuan dan sikap dalam setiap kehidupan (C. Geertz, 2001; Tago \& Shonhaji, 2017). Pendapat ini menegaskan bahwa budaya pada dasarnya merupakan hasil karya manusia, baik berbentuk nilai-nilai, aktivitas manusia dan benda. Budaya yang dimiliki oleh manusia dapat berkembang seiring dengan perkembangan zaman. Di sisi lain, budaya juga dapat mempengaruhi sikap dan perilaku manusia serta diwariskan dari generasi ke generasi berikutnya melalui proses interaksi sosial. Sedangkan budaya lokal pada dasarnya hasil karya manusia baik berupa nilai-nilai, aktivitas manusia atau benda dalam suatu komunitas atau etnik 
tertentu pada suatu daerah atau kelompok masyarakat sehingga membudaya dalam totalitas kehidupan (Brata, 2016; Digdoyo, 2019).

Budaya dapat diwujudkan dalam tiga hal, pertama: ide, konsep, gagasan, nilai, norma, dan peraturan. Kedua, kegiatan, yaitu tindakan berpola dari manusia dalam bermasyarakat. Ketiga, benda hasil karya manusia (Hapsari \& Soleh, 2018). Budaya mengacu pada nilai-nilai atau kode yang dilakukan oleh sekelompok orang (Hidayat \& Hafiar, 2019; Nuh \& Dardiri, 2017). Hal senada dikemukakan oleh (Krutzen et al., 2005) bahwa budaya pada dasarnya semua pengalaman seseorang dalam menjalani hidup.

Budaya lokal seringkali diartikan sebagai hasil cipta, karsa dan rasa asli dari sekelompok masyarakat pada suatu daerah tertentu. (Ajawaila, 2005), menjelaskan budaya lokal pada dasarnya merupakan ciri khas budaya yang dimiliki oleh sekelompok masyarakat lokal. Definisi budaya lokal sering dikaitkan dengan batas-batas fisik dan geografis, seperti budaya Jawa yang selalu dikaitkan dengan tradisi yang berkembang di Pulau Jawa (Permana, Kusdiana, \& Mawardi, 2021; Widyastuti, 2010). Oleh karena itu, dalam mendefinisikan budaya lokal, batasan geografis dijadikan landasan utama dalam merumuskan definisi budaya lokal. Namun, seiring dengan terjadinya proses perubahan sosial budaya, maka batas fisik dan geografis tidak lagi dijadikan landasan utama dalam mendefinisikan budaya lokal. Terlebih dengan adanya penyebaran budaya secara global melalui media massa dan media sosial, maka sulit sekali menemukan budaya lokal yang benar-benar asli dari kelompok masyarakat tertentu.

Salah satu ciri utama dari budaya lokal dapat dikenali dari bentuk kelembagaan sosial yang dimiliki oleh suatu suku bangsa. Kelembagaan sosial adalah ikatan sosial yang menyatukan dan mengkoordinir tindakan sosial yang dilakukan oleh anggota masyarakat (Warsah et al., 2020; Widyastuti, 2010). Lembaga sosial ini memiliki kekuatan mengikat perilaku sosial masyarakat. Beberapa bentuk kelembagaan sosial yang ada di masyarakat misalnya sistem gotong royong pada masyarakat Jawa, upacara atau selamatan kelahiran, pernikahan dan sebagainya (Idi Warsah, 2018).

Berpijak dari beberapa definisi adat dan budaya sebagaimana dikemukakan di atas dapat dipahami bahwa budaya lokal merupakan kebudayaan yang dimiliki dan diakui, oleh masyarakat serta tumbuh dan berkembang pada suatu daerah tertentu yang diwariskan secara turun temurun. Budaya lokal akan muncul jika penduduk suatu daerah sudah memiliki pola pikir dan kehidupan sosial yang sama. Kemudian kebudayaan tersebut menjadi suatu kebiasaan masyarakat pada suatu daerah, baik yang berkaitan dengan cara hidup maupun berkaitan dengan interaksi sosial, sehingga membedakan dengan daerah lain (Krismoniansyah et al., 2020).

Setiap masyarakat mempunyai kebudayaan tersendiri menurut kebangsaan, kesukuan, adat istiadat, agama dan sejarah perkembangan masing-masing. Indonesia memiliki lebih 300 suku bangsa dan 250 bahasa (Geertz et al., 1981). Namun data BPS menunjukkan bahwa Indonesia memiliki 633 suku dan sub suku (Pitoyo \& Triwahyudi, 2018), dan 742 bahasa (Hidayat \& Hafiar, 2019). Masingmasing suku bangsa mempunyai karakteristik budaya lokal yang berbeda pula. Dalam masyarakat yang pluralistik sangat sukar menentukan kebudayaan yang "sama", sehingga akan muncul masalah kebudayaan yang dianggap "berbeda" itu dianggap "asing" oleh masyarakat yang berbeda kebudayaannya, bahkan tidak jarang menimbulkan perpecahan di kalangan masyarakat. Kebudayaan yang dianggap "sama" biasanya cenderung lebih mudah menyatu dan diterima oleh masyarakat yang memiliki kesamaan kebudayaan.

Secara etimologi, multikultural berasal dari dua kata, multi dan kultural. Multi berarti banyak atau lebih dari satu, kultural bermakna budaya (Astawa, 2016). Secara bahasa masyarakat multikultural berarti sekelompok manusia yang memiliki banyak kebudayaan. Istilah multikultural digunakan untuk menggambarkan adanya beberapa budaya dalam satu masyarakat (Firdaus, Anggreta, \& Yasin, 2020). Masyarakat multikultural adalah suatu masyarakat yang terdiri dari dua atau lebih elemen yang hidup sendiri-sendiri tanpa ada pembauran satu sama lain di dalam satu kesatuan politik (Hidayat, Kuswarno, Zubair, \& Hafiar, 2017). Menurut Geertz et al. (1981) dalam Nurhayati dan Agustin ( 2020), masyarakat multikultural merupakan masyarakat yang terbagi dalam sub-subsistem yang kurang lebih berdiri sendiri dan masing-masing subsistem teikat oleh ikatan- 
ikatan primordial. Nasikun mengemukakan, masyarakat multikultural adalah suatu masyarakat bersifat majemuk, secara struktur masyarakat memiliki sub-sub kebudayaan yang bersifat diverse yang ditandai oleh kurang berkembangnya sistem nilai yang disepakati oleh seluruh anggota masyarakat dan juga sistem nilai dari satu-kesatuan sosial (Sukarniti, 2020). Mudzhar (2017) lebih menekankan bahwa dalam masyarakat multikultural adalah masyarakat yang penuh dengan keragaman baik keragaman nilai-nilai, sistem, budaya, kebiasaan, dan politik yang dianut oleh masyarakat. Masyarakat multikultural adalah masyarakat yang terdiri atas berbagai macam suku yang masing-masing mempunyai struktur budaya (culture) yang berbeda-beda (Gunawan \& Rante, 2011). Masyarakat multikultural terbentuk karena adanya keanekaragaman budaya (Warsah et al., 2019).

Masyarakat multikultural memiliki beberapa karakteristik, yaitu:

1. Adanya segmentasi. Segmentasi berarti masyarakat tersebut dibentuk oleh bermacam-macam budaya, suku, adat istiadat dan sebagainya dan memiliki pemisah yang biasanya berupa konsep yang sering disebut primordial atau ikatan kedaerahan.

2. Memiliki struktur dalam lembaga yang non-komplementer, maksudnya adalah dalam masyarakat multikultural biasanya ada suatu lembaga yang mengalami kesulitan dalam menjalankan atau mengatur masyarakatnya. Hal ini disebabkan karena kurang lengkapnya persatuan yang terpisah oleh segmen-segmen tertentu.

3. Konsensus rendah, maksudnya adalah kesepakatan dalam pengambilan keputusan sangat sulit untuk diwujudkan.

4. Rentan adanya konflik.

5. Adanya dominasi dari kelompok lain (Suparlan, 2014).

Masyarakat multikultural bersifat heterogen. Walaupun demikian memiliki hubungan sosial antar anggota masyarakat bersifat toleran, hidup berdampingan dan saling menghargai terhadap perbedaan. Suatu masyarakat dikatakan multikultural jika dalam masyarakat tersebut memiliki keanekaragaman dan perbedaan budaya yang berakar pada perbedaan standar nilai yang berbedabeda, keragaman ras, suku, dan agama.

\section{Kenduri Kawin atau Walimatul ‘Ursy}

Kenduri atau kenduren merupakan tradisi Jawa lama yang sampai saat ini masih dilestarikan oleh suku Jawa di mana saja mereka berada. Kenduri ini dilakukan ketika selamatan atau berdoa dengan mengundang para tetangga sekitar. Pelaksanaan kenduri biasanya selain disiapkan makanan dan minuman oleh tuan rumah juga diisi dengan doa-doa kepada para leluhur yang dipimpin oleh pemuka adat, kiyai atau orang yang dituakan dalam kelompok tersebut dan sudah terbiasa memimpin acara kenduri (Purnama \& Nurman, 2018).

Dalam Kamus Bahasa Indonesia, kenduri diartikan sebagai perjamuan makan. Jamuan makan tersebut dilakukan dalam rangka memperingati suatu peristiwa, meminta berkah, dan sebagainya (Waridah, 2017). Istilah Kenduri dalam bahasa Jawa yang lebih dikenal dengan sebutan Selamatan atau Kenduren (Santosa, Agustina, \& Yulianti, 2020; Susanti, 2017). Istilah kenduren berasal dari bahasa Parsi: kanduri artinya, pesta makan setelah dibacakan doa pada peringatan kematian (Daryono, 2018). Istilah kenduri atau selamatan atau kenduren bagi masyarakat Jawa sesungguhnya telah ada sejak dahulu sebelum masuknya agama ke Nusantara.

Menurut Simuh, dalam (Hudha, 2020) kenduri atau selamatan atau kenduren merupakan budaya Jawa yang berasal dari keyakinan animisme, dinamisme dan Hindu-Budda yang sudah ada sejak sebelum Islam datang ke tanah Jawa. Walaupun secara komunitas, masyarakat Jawa sudah memeluk Islam namun tradisi dan pola-pola keberagamaannya masih dipengaruhi oleh keyakinan dan tradisi-tradis pra-Islam, salah satu tradisi tersebut diantaranya adalah kenduri. Hilmi dalam (Hasbullah, Toyo, \& Awang Pawi, 2017) menjelaskan, selamatan atau kenduri merupakan upacara ritual yang sudah menjadi tradisi, khususnya pada masyarakat Jawa. Kholil (2010) menjelaskan upacara ritual dalam bentuk kenduri atau selamatan biasanya dilakukan pada suatu acara atau 
peristiwa yang sangat penting dialami oleh seseorang, seperti kelahiran, pernikahan, sunatan atau khitan, membangun rumah, memperingati roh leluhur, perayaan hari besar dan sebagainya. Kenduri kawin atau walimatul 'ursy adalah selamatan, doa atau resepsi yang dilakukan setelah acara pernikahan (Maulidiyah, 2019).

\section{Walimatul 'Ursy sebagai suatu tradisi masyarakat Barumanis}

Masyarakat di desa Barumanis pada umumnya masih memegang teguh tradisi yang diwariskan oleh leluhurnya. Salah satu tradisi yang masih ada sampai sekarang adalah tradisi kenduri kawin atau walimatul "ursy. Masyarakat desa Barumanis sering menyebut "kenduren atau selametan". Kenduren atau selametan merupakan tradisi masyarakat desa Barumanis untuk mengungkapkan rasa syukur setelah mendapatkan suatu nikmat atau meminta berkah kepada Allah SWT. Kenduri kawin atau walimatul 'ursy dilaksanakan setelah sepasang laki-laki dan perempuan selesai melaksanakan akad nikah. Kenduri walimah dimaksud sebagai ucapan syukur dan permohonan kepada Allah SWT agar kedua mempelai diberi keselamatan, kelancaran, kebahagiaan dan terhindar dari mara bahaya selama mengarungi bahtera rumah tangga.

Kenduri kawin atau walimatul 'ursy biasanya dilaksanakan pada siang hari. Dalam acara tersebut diiringi dengan kegiatan acara makan bersama dengan masyarakat yang diundang. Masyarakat yang menghadiri acara kenduri kawin adalah laki-laki, sementara kaum perempuan (ibu-ibu) sibuk mempersiapkan makanan atau jamuan. Jika yang mempunyai hajatan kenduri walimah adalah masyarakat muslim, biasanya ada beberapa rangkaian acara yang dilaksanakan dalam kenduri kawin, membaca ayat suci al Quran, kata sambutan, ceramah agama, doa kepada leluhur dan makan bersama. Namun apabila yang punya hajatan masyarakat nonmuslim, biasanya hanya kata sambutan dan makan bersama (Saring, Komunikasi Personal, 3 Oktober 2019).

Kenduri kawin bagi masyarakat desa Barumanis dimaknai sebagai ungkapan rasya syukur dan pengharapan kepada Yang Maha Kuasa. Bersukur karena anaknnya sudah dipertemukan jodohnya oleh Yang Maha Kuasa, dan memohon agar rumah tangga yang dibina menjadi keluarga yang sakinah, mawadah, warahmah dan terhindar dari mara bahaya. Hal ini sejalan dengan beberapa studi yang menunjukkan bahwa dengan bersyukur akan melahirkan pandangan yang positif dalam kehidupan, mendapatkan kepuasan secara emosional dan interpersonal sehingga mampu meningkatkan coping dan membawa individu pada kehidupan ke arah yang positif (Utami, Sanjiwani, Widiastuti, Pradnyadani, \& Paramitha, 2018). Di sisi lain, dengan bersyukur dapat mencegah depresif dan patologis (Wijayanti, Rahmatika, \& Listiyandini, 2020).

Kenduri kawin atau walimatul 'ursy merupakan salah satu tradisi yang ada di desa Barumanis, Kecamatan Bermani Ulu Kabupaten Rejang Lebong. Tradisi kenduri kawin banyak memiliki nilai positif bagi kehidupan bermasyarakat di desa Barumanis. Salah satu nilai positif tersebut adalah dapat memupuk semangat toleransi antar umat beragama, dapat meningkatkan semangat kerja sama, saling tolong menolong, meningkatkan silaturahmi dan sebagainya. Oleh karena itu, tradisi kenduri kawin tersebut perlu dilestarikan agar tidak punah. Hal ini sesuai dengan hasil wawancara yang peneliti lakukan sebagai berikut:

Kenduri kawin merupakan salah satu tradisi yang masih tetap ada dan dilaksanakan oleh masyarakat desa Barumanis. Sebagai suatu tradisi yang sudah dilaksanakan secara turun temurun. Di sisi lain, tradisi kenduri kawin memiliki banyak nilai positif, seperti ada nilai toleransi, memupuk semangat gotong royong, bekerjasama, saling bantu membantu dan sebagainya. Oleh karena itu tradisi kenduri kawin perlu dilestarikan dengan terus dilaksanakan secara turun temurun (Sumarno, komunikasi personal, 5 Oktober 2019).

Hal senada dikemukakan oleh Pelaksana Tugas (Plt) Kepala Desa Barumanis, yang menyatakan bahwa:

Kenduri kawin merupakan salah satu tradisi yang ada di desa Barumanis. Tradisi kenduri kawin ini banyak sekali nilai positifnya, seperti untuk mempererat silaturahmi, memupuk semangat saling membantu, saling menolong, peduli terhadap sesama dan sebagainya. Tradisi kenduri 
kawin ini perlu dilaksanakan dan wariskan dari genareasi ke generasi berikutnya agar tetap lestari. Aparat desa sepenuhnya mendukung segala upaya untuk melestarikan kenduri kawin ini (Bastari, Komunikasi Personal, 3 Oktober 2019).

Menurut Bastari, Kepada Desa Barumanis Kecamatan Bermani Ulu Kabupaten Rejang Lebong, tidak ada upaya khusus yang dilakukan pemerintah desa untuk melestarikan tradisi kenduri kawin tersebut. Pemerintah desa Barumanis pernah mengusulkan agar tradisi kenduri kawin tetapkan sebagai tradisi yang harus dilaksanakan oleh masyarakat dan ditetapkan sanksi-sanksi tertulis bagi yang tidak melaksanakan. Namun seluruh tokoh masyarakat menolaknya. Hal ini dikhawatirkan akan memberatkan masyarakat dan menyebabkan tradisi kenduri kawin akan hilang. Hal ini sesuai dengan hasil wawacara yang peneliti lakukan sebagai berikut:

Pemerintah desa telah mengusulkan agar kenduri kawin ditetapkan melalui peraturan desa sebagai tradisi yang harus dilaksanakan oleh setiap masyarakat dan dilengkapi bentuk-bentuk sanksi bagi masyarakat yang melanggarnya. Namun seluruh tokoh masyarakat yang ada di desa Barumanis menolaknya. Hal ini disebabkan karena dikuatirkan peraturan desa itu justru dapat memberatkan masyarakat. Masyarakat merasa terpaksa melaksanakan kenduri kawin. Dikuatirkan ke depannya justru akan menyebabkan tradisi kenduri kawin hilang (Bastari, Komunikasi Personal, 3 Oktober 2019).

Pernyataan Bastari dibenarkan oleh salah beberapa tokoh masyarakat desa Barumanis yang menyatakan bahwa:

Memang benar bahwa dulu pemerintah desa Barumanis pernah mengusulkan agar dibuat peraturan desa. Peraturan desa tersebut memuat tentang pelaksanaan tradisi-tradisi masyarakat di desa Barumanis, salah satu diantaranya adalah tentang tata cara pelaksanaan kenduri kawin. Selain itu juga didalamnya memuat sanksi-sanksi yang akan diterima jika hal tersebut tidak dilaksanakan. Namun hal tersebut ditolak oleh tokoh masyarakat. Hal ini disebabkan karena dikuatirkan hal itu akan memberatkan masyarakat. Walaupun demikian tradisi kenduri kawin tersebut penting untuk dilestarikan. Salah satu cara melestarikan adalah dengan sanksi sosial bagi anggota masyarakat yang tidak pernah hadir dalam acara kenduri kawin (M. Sali, Komunikasi Personal, 3 Oktober 2019).

Peraturan tertulis terkait dengan kenduri kawin belum ada. Namun peraturan yang tidak tertulis yang berupa kesepakatan masyarakat sudah ada sejak zaman dulu. Kesepakatan masyarakat yang tidak tertulis tersebut berupa sanksi sosial bagi masyarakat yang tidak pernah hadir dalam acara kenduri kawin masyarakat setempat. Artinya jika kita tidak pernah hadir dalam acara-acara kegiatan kemasyarakatan, termasuk acara kenduri kawin, maka suatu ketika jika kita punya hajatan masyarakat pun tidak akan mau hadir ke tempat kita (Saring, Komunikasi personal, 3 Oktober 2019).

Walaupun demikian, tradisi kenduri kawin di desa Barumanis tetap dilestarikan. Hal ini terlihat dengan adanya "adanya kesepakatan masyarakat untuk tetap melaksanakan tradisi tersebut, adanya kesadaran warga untuk melaksanakan dan menghadiri undangan kenduri kawin serta diwariskan dari generasi ke generasi berikutnya (M. Sali, wawancara pribadi, 3 Oktober 2019)". Hal ini sejalan dengan hasil penelitian yang mengemukakan bahwa aspek penting yang harus dilakukan dalam melestarikan budaya adalah melaksanakan budaya, adanya partisipasi masyarakat dan mewariskan budaya tersebut kepada generasi berikutnya (Purnama \& Nurman, 2018; Wibisono, 2015). Melestarikan tradisi juga dapat dilakukan dengan merawat, memelihara dan mewariskan kepada generasi berikutnya melalui lembaga pendidikan (Rahmawati, 2019). Pelestarian tradisi akan lebih kuat jika tradisi tersebut dilembagakan secara formal, disepakati oleh seluruh masyarakat dan ditetapkan secara secara tertulis (Herningsih, 2018).

Berdasarkan hasil wawancara yang telah dipaparkan di atas dapat diketahui bahwa kenduri kawin atau walimatul 'ursy merupakan suatu tradisi masyarakat desa Barumanis diwariskan secara 
turun temurun. Masyarakat meyakini bahwa tradisi tersebut banyak memiliki nilai positif dan perlu dilestarikan. Nilai positif tersebut diantaranya dapat memupuk semangat semangat gotong royong, toleransi, saling kerja sama dan membantu antar sesama walau dalam perbedaan agama, suku dan budaya. Pelestarian tradisi kenduri kawin atau walimatul 'ursy di desa Barumanis masih seperti pelestarian tradisi-tradisi pada umumnya, yaitu adanya komitmen dan kesadaran masyarakat untuk tetap melaksanakan, diwariskan secara turun temurun dan adanya sanksi sosial secara tidak tertulis.

\section{Makna Tradisi Walimatul 'Ursy bagi masyarakat Barumanis}

Hasil penelitian menunjukkan bahwa masyarakat desa Barumanis Kabupaten Rejang Lebong memaknai kenduri kawin atau walimah 'ursy sebagai berikut :

\section{Memiliki nilai transendental}

Masyarakat desa Barumanis Kecamatan Bermani Ulu Kabupaten Rejang Lebong meyakini bahwa kenduri termasuk kenduri walimah memiliki nilai transendental. Nilai transendental yang dimaksud di sini adalah memiliki abstrak yang melampaui batas-batas pengalaman manusia. Bagi masyarakat desa Barumanis, tidak melaksanakan tradisi kenduri, seperti kenduri suroan, kenduri ulang tahun tani dan sebagainya maka diyakini akan tertimpa bala' atau bencana.

Begitu juga halnya dengan tradisi kenduri kawin, bagi masyarakat beranggapan bahwa jika setelah akad nikah tidak melakukan kenduri kawin, maka nikahnya belum sempurna dan diyakini kehidupan rumah tangganya tidak akan bahagia. Oleh karena itu, setiap masyarakat desa Barumanis melestarikan tradisi kenduri kawin. Ada beberapa nilai transendental dalam tradisi kenduri kawin bagi masyarakat desa Barumanis, yaitu dapat memberikan keselamatan dan kebahagiaan bagi mempelai, serta dapat menjadikan mempelai tidak bahagia jika tidak dilaksanakan. Hal ini sesuai dengan hasil wawancara sebagai berikut:

Kenduri kawin atau walimatul 'ursy merupakan bagian terpenting dalam upacara pernikahan. Di samping untuk memberitahu jiran tetangga bahwa telah dilaksanakan akad nikah sepasang remaja atau manusia, juga dilaksanakan kenduri kawin merupakan tradisi yang memiliki nilai sakral. Karena dalam kenduri kawin ada ritual-ritual yang berupa doa memohon kepada Allah SWT agar kedua mempelai diberi keselamatan dan kebahagiaan. Di sisi lain, dalam kenduri kawin atau walimatul 'ursy juga dibacakan tahlil yang dihadiahkan kepada arwah anggota keluarga yang sudah meninggal (bapak, ibu, kakek, atau nenek dan sebagainya). Maka jika setelah akad nikah tidak melakukan kenduri walimah, ya.....kasihan mbah-mbah yang sudah meninggal, nanti kalau tidak merestui bagaimana? Akibatnya bisa jadi yang melangsungkan pernikahan hidupnya tidak akan bahagia (M. Sali, Komunikasi Personal, 3 Oktober 2019).

Hal senada dikemukakan oleh Saring. Menurut Saring kenduri kawin merupakan tradisi yang harus dilaksanakan bagi setiap warga yang melaksanakan akad nikah. Saring menjelaskan sebagai berikut:

Kenduri kawin itu kan merupakan tradisi dan warisan pendahulu kita, ya...harus dilaksanakan. Kalau tidak bisa kualat jika tidak pamit dan mengirim tahlil kepada mbah-mbah yang telah meninggal dunia. Kenduri kawin di samping berdoa kepada Yang Maha Kuasa, juga mengirim tahlil kepada ahli waris yang telah meninggal dunia. Ya...istilahnya minta izin dan restu kepada mbah-mbah yang telah meninggal agar didoakan kedua mempelai diberi kelanggengan dan kebahagiaan rumah tangganya (Saring, Komunikasi Personal, 3 Oktober 2019).

Dalam kenduri kawin, selain dilakukan doa bersama, jika anggota keluarganya ada yang telah meninggal dunia, seperti orang tuanya, mbah, nenek dan sebagainya, maka sebelum akad nikah biasnya berziarah ke makam ahli waris yang telah meninggal dunia. Doa bersama dan ziarah kubur tujuannya adalah untuk memohon kepada yang Maha Kuasa agar mempelai diberikan kebahagiaan, kelangengan dan terhindar dari marabahaya (Samad \& Munawwarah, 2020). Nilai transendental inilah yang menjadi motivasi bagi masyarakat desa Barumanis melaksanakan tradisi kenduri kawin yang dalam prakteknya mengundang masyarakat sekitar tanpa membedakan suku, bahasa, budaya 
bahkan agama. Adanya kesamaan pemahaman dan persepsi inilah yang mampu menjadi perekat kesatuan dalam perbedaan (Lubis, 2017).

\section{Memupuk semangat kesatuan}

Desa Barumanis Kecamatan Bermani Ulu Kabupaten Rejang Lebong merupakan salah satu desa yang masyarakatnya masih memegang teguh tradisi. Salah satu tradisi yang masih dilaksanakan sampai saat ini adalah kenduri. Suku Rejang menyebut dengan istilah kendurai, kenduri pada suku Jawa, kerje atau bepelan pada suku Lembah dan mendoa pada suku Minang (M. Sali, Komunikasi Personal, 3 Oktober 2019). Kesemuanya itu memiliki makna yang sama, yaitu berdoa untuk memohon keselamatan atau bentuk ucapan syukur kepada Tuhan (Susanti, 2017).

Berdasarkan hasil penelitian, dapat diketahui bahwa, selain kenduri kawin atau walimatul 'ursy, di desa Barumanis ada tradisi kenduri menyambut bulan Ramadhan, kenduri menyambut hari raya idul fitri, kenduri arwah dan kenduri kelahiran bayi atau puputan. Pada tradisi kenduri tersebut, ahli rumah mengundang masyarakat setempat untuk berdoa bersama dan makan bersama. Doa biasanya dipimpin oleh tokoh agama setempat (Saring, Komunikasi Personal, 3 Oktober 2019).

Tradisi kenduri kawin yang dilaksanakan masyarakat desa Barumanis, dilakukan dengan cara mengundang warga sekitar tanpa membedakan suku, budaya dan kepercayaan atau agama (Samuji, Komunikasi Personal, 5 Oktober 2019). Beberapa rangkaian acara yang dilakukan pada acara kenduri kawin diantaranya pembacaan ayat suci al Quran, ceramah agama, doa bersama dan diakhiri dengan makan bersama (Sumarno, Komunikasi Personal, 5 Oktober 2019). Kenduri dalam menyambut bulan Ramadhan, menyambut hari raya idul fitri dan kenduri arwah, mengundang warga tanpa membedakan suku dan budaya, dilakukan doa bersama dengan tahlilan yang pahalanya ditujukan kepada keluarga yang telah meninggal dunia dan diakhiri dengan makan bersama (Ponidi, Komunikasi Personal, 3 Oktober 2019). Begitu juga halnya dengan kenduri kelahiran bayi atau puputan, juga mengundang jiran tetangga tanpa membedakan suku dan budaya, namun sebelum doa bersama dilakukan acara marhaban, setelah itu diakhiri dengan makan bersama (M. Sali, Komunikasi Personal, 3 Oktober 2019).

Tradisi kenduri, termasuk kenduri kawin atau walimah 'ursy yang dilaksanakan di desa Barumanis dapat menjadi salah satu instrumen untuk menayatukan warga masyarakat yang berbeda suku, budaya dan bahasa. Hadirnya warga masyarakat yang memiliki perbedaan suku, budaya dan bahasa hadir dalam suatu acara kenduri terjadi karena danya persamaan masyarakat dalam memaknai kenduri kawin. Kenduri kawin bukan hanya sebatas doa bersama dan makan bersama, melainkan juga ada semangat saling menghargai dan menghormati antar sesama dalam perbedaan suku, budaya dan bahasa, inilah unsur penting yang harus ada dalam masyarakat multikultural (Daiman \& Iswahyudi, 2019). Selain itu, kehadiran warga masyarakat dalam pelaksanaan tradisi kenduri tersebut, dapat mempererat silaturahim dan memupuk kesatuan dalam perbedaan suku, budaya, bahasa dan sebagai wujud adanya ketaatan sosial (Budiman, 2018).

\section{Memperkuat semangat gotong royong dan saling membantu}

Kenduri walimah juga memiliki nilai gotong royong dan saling membantu antara satu keluarga dengan keluarga lainnya. Nilai gotong royong tersebut tercermin dalam partisipasi masyarakat untuk menyukseskan tradisi kenduri kawin tersebut. Partisipasi masyarakat tersebut terlihat dengan dibentuknya panitia kerja, adanya gotong royong masyarakat dalam tegak tarub atau mendirikan tenda dan adanya ibu-ibu di sekitar yang membawa ayam, beras dan atau perlengkapan masak lainnya untuk acara jamuan kenduri kawin tersebut. Hal ini sesuai dengan kutipan wawancara sebagai berikut:

Dalam kenduri kawin di desa Barumanis, masyarakat saling tolong menolong, bekerja sama dan bergotong royong untuk menyukseskan acara ini. Sebelum kenduri kawin dimulai, biasanya diadakan rapat pembentukan panitia kerja. Dalam panitia kerja tersebut ada ketua, wakil ketua, 
seksi tarub (tenda), seksi masak, seksi pembawa acara, seksi hidangan, keamanan, tukang parkir dan sebagainya. Panitia kerja tersebut bekerja mulai tegak atau mendirikan tarub sampai membongkar tarub. Semua masyarakat sekitar, baik muslim maupun non-muslim berkewajiban untuk menyukseskan acara kenduri kawin ini semua (Warsito, Komunikasi Personal, 7 Oktober 2019).

Semangat gotong royong menjelang kenduri kawin atau walimatul 'ursy juga terlihat keikutsertaan warga dalam menyaksikan kegiatan hantaran dan akad nikah. Samuji menjelaskan sebagai berikut:

Tradisi masyarakat desa Barumanis ketika ada warga yang melaksanakan hajatan pernikahan, warga saling bantu membantu. Misalnya dalam acara hantaran dan akad nikah, warga sekitar hadir untuk menyaksikan dan membantu agar pelaksanaan acara tersebut dapat berjalan dengan lancar. Di acara kenduri kawin, ada juga yang ikut serta dalam membagikan hidangan, menyambut tamu, mengatur tempat parkir tamu undangan dan sebagainya (Samuji, Komunikasi Personal, 5 Oktober 2019).

Hal senada dikemukakan oleh Tumisem yang menjelaskan bahwa dalam kenduri kawin, nilai kegotong-royongan terlihat dengan adanya ibu-ibu saling bantu membantu dalam mempersiapkan makanan untuk acara walimahan. Tumisem menjelaskan sebagai berikut:

Ibu-ibu warga desa Barumanis ketika ada acara kenduri kawin juga ikut rewang, yaitu membantu untuk mempersiapkan hidangan makanan. Ibu-ibu ada yang membawa ayam, beras, gula, dan bahan-bahan masak lainnya serta bantu membantu dalam memasak makanan. Hal ini sudah berlangsung sangat lama dan turun temurun. Kita hidup di masyarakat, harus saling bantu membantu jika ada tetangga yang melaksanakan hajatan. Dengan saling bantu membantu ini, ke depan jika kita melaksanakan hajatan orang dan tetangga pung akan membantu kita. Berat sama dipikul ringan sama dijinjing (Tumisem, Komunikasi Personal, 5 Oktober 2019).

Semangat gotong royong dan saling bantu membantu dalam acara kenduri kawin jika dihayati secara mendalam dilandasi keikhlasan, kebersamaan, kesatuan, kesatuan dan timbal balik (Widawati, Muzaiyana, \& Ferian, 2018). Semangat keikhlasan, kebersamaan dan kesatuan terlihat bahwa warga yang datang menghadiri acara walimah, mulai menghadiri acara hantaran, tegak atau memasang tarub, menghadiri prosesi pernikahan, rewang atau membantu menyiapkan makanan, menyambut tamu undangan sampai membongkar tarub atau tenda dilakukan secara suka rela untuk membantu menyukseskan acara kenduri kawin atau walimatul 'ursy jiran tetangga tanpa mengharapkan apapun. Bahkan masyarakat hanya diberi hidangan makan dan minum.

"Hubungan Timbal balik" atau reprositas juga melandasi semangat gotong royong dan saling membantu dalam kenduri kawin. Dalam teori sosial, perlakuan seseorang kepada orang lain akan berdampak pada perlakuan orang lain kepada dirinya (H. Panjaitan, 2014). Jika seseorang dalam suatu masyarakat suka membantu dan menolong sesama warga dalam kegiatan sosial kemasyarakatan termasuk dalam kenduri kawin, maka suatu saat ketika ia melaksanakan kenduri kawin, maka masyarakat diharapkan dapat membantu dan menolongnya.

\section{Memupuk semangat toleransi}

Kenduri atau walimah merupakan salah satu rangkaian acara dalam prosesi pernikahan. Sebelum acara kenduri atau walimah dilaksanakan, khususnya bagi masyarakat muslim biasannya diawali dengan hantaran, rapat pembentukan panitia, prosesi akad nikah, baru dilanjutkan dengan acara kenduri atau walimah. Hal ini sesuai dengan keterangan salah seorang tokoh masyarakat desa Barumanis Kecamatan Bermani Ulu Kabupaten Rejang Lebong sebagai berikut :

Sebelum acara kenduri kawin atau walimatul 'ursy, khusus bagi masyarakat muslim biasanya didahului beberapa rangkaian acara, diantaranya adalah ada lamaran atau hantaran, rapat pembentukan panitia tarub, prosesi akad nikah baru dilanjutkan dengan acara kenduri atau walimah. Masyarakat biasanya jika ada salah seorang warga yang akan melangsungkan kenduri 
atau walimah saling tolong menolong dan membantu untuk kesuksesana acara tersebut (Ponidi, Komunikasi Personal, 3 Oktober 2019).

Kenduri kawin atau walimatul 'ursy dilakukan setelah akad nikah yang dilaksanakan dengan berkumpul bersama pada umumnya laki-laki, doa bersama untuk leluhur dan diselingi dengan ceramah agama. Hal senada diungkapkan oleh tokoh masyarakat desa Barumanis, beliau mengatakan sebagai berikut:

Salah satu tradisi yang masih dipegang teguh oleh masyarakat desa Barumanis Kecamatan Bermani Ulu Kabupaten Rejang Lebong adalah kenduri kawin. Kenduri kawin merupakan kenduri yang dilaksanakan oleh masyarakat ketika selesai melangsungkan akad nikah. Kenduri kawin tersebut disebut juga dengan istilah kenduren atau selamatan yang dilakukan dalam rangka ucapan syukur kepada Yang Kuasa karena acara akad nikah sudah dilaksanakan secara aman, selamat dan lancar. Kenduri walimah juga bertujuan untuk memohon kepada Yang Kuasa agar pengantin khususnya dan masyarakat pada umumnya dilindungi oleh Yang Kuasa dari segala macam mara bahaya (M. Sali, Komunikasi Personal, 05 Oktober 2019).

Sejalan dengan pernyataan Suherwan, Sutiyoso juga mengatakan bahwa kenduri kawin di desa Barumanis dihadiri oleh masyarakat sekitar, baik muslim maupun nonmuslim. Hal ini sesuai dengan hasil wawancara sebagai berikut:

Dalam acara kenduri kawin di desa Barumanis Kecamatan Bermani Ulu Kabupaten Rejang Lebong yang diundang itu semua warga sekitar tanpa memandang perbedaan agama dan suku. Biasanya warga sekitar yang diundang acara kenduri kawin akan hadir. Jika yang mengadakan walimah itu orang muslim, warga nonmuslim dan penganut aliran kepercayaan diundang dan menghadirinya bahkan ikut berdoa bersama dan mendengarkan ceramah agama. Begitu juga sebaliknya, jika yang punya hajatan warga nonmuslim, orang muslim pun diundang dan menghadirinya (Sutiyoso, Komunikasi Personal, 05 Oktober 2019).

Semangat toleransi memiliki peran yang sangat penting dalam membangun kebersamaan dalam perbedaan keyakinan (Panjaitan \& Dewantara, 2019). Semangat toleransi ini dibuktikan dengan kehadiran warga yang berbeda keyakinan. Kehadiran warga yang berbeda keyakinan dalam acara kenduri kawin atau walimatul 'ursy menunjukkan adanya toleransi yang tinggi terhadap sesama warga yang berbeda keyakinan. Secara normatif, nilai-nilai agama dan budaya menjadi landasan utama dalam mewujudkan toleransi. Secara empirik, nilai kemanusiaan, nilai nasionalisme dan keteladanan tokoh masyarakat menjadi unsur penting dalam menciptakan toleransi dalam kehidupan bermasyarakat (Naim, 2017; Nisvilyah, 2013).

Berdasarkan hasil penelitian dapat diketahui bahwa faktor penyebab yang menjadikan kenduri kawin menjadi perekat kesatuan adalah : Pertama, adanya kesamaan masyarakat dalam memaknai kenduri kawin. Kenduri kawin bukan hanya sebatas doa bersama dan makan bersama, melainkan juga sebagai wujud adanya saling menghargai dan menghormati antar sesama dalam perbedaan. Kedua, adanya kesamaan keyakinan. Kenduri kawin diyakini memiliki nilai transendental yang akan membawa kebahagiaan mempelai jika dilaksanakan, akan menimbulkan musibah jika tidak dilaksanakan. Ketiga, kenduri kawin memiliki nilai gotong royong dan saling membantu. Hasil penelitian tersebut sejalan dengan pendapat yang menyatakan, ada beberapa aspek yang dapat menjadi perekat kesatuan, diantaranya adalah adanya kesamaan persepsi dan pandangan (Dewi, Supriyadi, \& Dasuki, 2018), adanya kesamaan keyakinan (Jati, 2013), adanya kesamaan sosial budaya dan adanya kesamaan asal usul (Brata, 2016; Fuadi, 2020). Semakin banyak kesamaan yang dimiliki maka akan semakin kuat dalam merekat persatuan dan kesatuan. "Kesamaan" memiliki peran yang sangat penting sebagai perekat kesatuan dalam bermasyarakat dan bernegara. "Kesamaan" inilah yang perlu dicari dan digali dalam mewujudkan persatuan dan kesatuan.

\section{Kesimpulan}

Kenduri kawin atau walimatul 'ursy bagi masyarakat desa Barumanis Kabupaten Rejang Lebong merupakan suatu tradisi dan tetap dilestarikan karena memiliki nilai positif bagi kehidupan 
masyarakat. Tradisi tersebut dilestarikan dengan meningkatkan komitmen dan kesadaran masyarakat, diwariskan secara turun temurun dan adanya sanksi sosial secara tidak tertulis. Masyarakat memiliki kesamaan dalam memaknai kenduri kawin atau walimatul 'ursy. Kesamaan dalam memaknai inilah yang menjadikan kenduri kawin atau walimatul 'ursy mampu menjadi perekat masyarakat multikultural khususnya di Desa Barumanius. Masyarakat Desa Barumanis memaknai keduri kawin memiliki nilai transendental, memupuk semangat kesatuan, memperkuat semangat gotong royong, saling membantu dan toleransi.

\section{Referensi}

A. Samad, S. A., \& Munawwarah, M. (2020). Adat Pernikahan dan Nilai-Nilai Islami dalam Masyarakat Aceh Menurut Hukum Islam. El-Usrah: Jurnal Hukum Keluarga, 3(2), $289-302$. https://doi.org/10.22373/ujhk.v3i2.7716

Abdullah, I. (2014). Penggunaan dan Penyalahgunaan Kebudayaan di Indonesia: Kebijakan Negara dalam Pemecahan Konflik Etnis. Antropologi Indonesia, 66, 34-45. https://doi.org/10.7454/ai.v0i66.3421

Ajawaila, J. W. (2005). Dinamika Budaya Orang Maluku. Maluku Menyambut Masa Depan. Ambon: Lembaga Kebudayaan Daerah Maluku.

Astawa, I. M. O. (2016). Kinerja Konselor dalam Mempersiapkan Generasi Emas pada Masyarakat Multi Kultural dan Modern. Jurnal Penjaminan Mutu, 2(2), 109-126. https://doi.org/10.25078/jpm.v2i2.77

Bauto, L. M. (2016). Perspektif Agama dan Kebudayaan dalam Kehidupan Masyarakat Indonesia (Suatu Tinjauan Sosiologi Agama). Jurnal Pendidikan Ilmu Sosial, 23(2), 11-25. https://doi.org/10.17509/jpis.v23i2.1616

Brata, I. B. (2016). Kearifan budaya lokal perekat identitas bangsa. Jurnal Bakti Saraswati (JBS), 5(1).

Budiman, E. A. (2018). Ketaatan Sosial Di Dalam Tradisi Saparan Pada Masyarakat Bandungrejo Kecamatan Ngablak Kabupaten Magelang Tahun 2018. IAIN Salatiga.

Daiman, M. A., \& Iswahyudi, D. (2019). Penanaman Toleransi Pada Mahasiswa PPKn Dari Berbagai Budaya. Prosiding Seminar Nasional Fakultas Ilmu Pendidikan, 3, 242-247.

Daryono. (2018). Berbagai Berkah Bid'ah Nyadran Dalam Budaya Islam Jawa. Jurnal Dinamika Sosial Budaya, 19(2), 209-220. https://doi.org/10.26623/jdsb.v19i2.982

Dewi, T. K. S., Supriyadi, H., \& Dasuki, S. (2018). Kearifan Lokal Mitos Pertanian Dewi Sri dalam Naskah Jawa dan Aktualisasinya sebagai Perekat Kesatuan Bangsa. Manuskripta, 8(2), 89-107. https://doi.org/10.33656/manuskripta.v8i2.116

Digdoyo, E. (2019). Rumah Puspo Budaya Nusantara Sebagai Pusat Pengembangan Pendidikan Karakter Melalui Tari Nusantara. Integralistik, 30(1), 62-99.

Edi, F. R. S. (2016). Teori Wawancara Psikodignostik. Yogyakarta: Leutika Prio.

Fargomeli, F. (2014). Interaksi Kelompok Nelayan dalam Meningkatkan Taraf Hidup di Desa Tewil Kecamatan Sangaji Kabupaten Maba Halmahera Timur. Acta Diurna Komunikasi, 3(3), 1-17.

Firdaus, F., Anggreta, D. K., \& Yasin, F. (2020). Internalizing Multiculturalism Values Through Education: Anticipatory Strategies for Multicultural Problems and Intolerance in Indonesia. Jurnal Antropologi: Isu-Isu Sosial Budaya, 22(1), 131. https://doi.org/10.25077/jantro.v22.n1.p131-141.2020

Fitri, S. (2017). Hukum memberi karangan bunga pada Walimatul Ur's (studi terhadap pandangan Majelis Ulama Indonesia kabupaten Labuhanbatu Selatan). Universitas Islam Negeri Sumatera Utara.

Fuadi, A. (2020). Keragaman Dalam Dinamika Sosial Budaya Kompetensi Sosial Kultural Perekat Bangsa. Yogyakarta: Deepublish.

Geertz, C. (2001). Agama sebagai Sistem Budaya. Yogyakarta: Qalam.

Geertz, H., Zainuddin, A. R., \& Ihromi, T. O. (1981). Aneka Budaya dan Komunitas di indonesia. Jakarta: Yayasan Ilmu-Ilmu Sosial \& FIS-UI.

Gunawan, K., \& Rante, Y. (2011). Manajemen konflik atasi dampak masyarakat multikultural di Indonesia. Jurnal Mitra Ekonomi Dan Manajemen Bisnis, 2(2), 212-224.

Hapsari, E. D., \& Soleh, D. R. (2018). Nilai Sosial Budaya dan Nasionalisme dalam Novel Burung-Burung Manyar Karya Yb. Mangunwijaya. Widyabastra: Jurnal Ilmiah Pembelajaran Bahasa dan Sastra Indonesia, 6(1), 1-15.

Hasan, M. A. K. (2016). Merajut Kerukunan dalam Keragaman Agama di Indonesia (Perspektif Nilai-Nilai AlQuran). Profetika: Jurnal Studi Islam, 14(1), 66-77.

Hasbullah, H., Toyo, T., \& Awang Pawi, A. A. (2017). Ritual Tolak Bala Pada Masyarakat Melayu (Kajian Pada Masyarakat Petalangan Kecamatan Pangkalan Kuras Kabupaten Pelalawan). Jurnal Ushuluddin, 25(1), 83100. https://doi.org/10.24014/jush.v25i1.2742 
Heradani, H. (2018). Tinjauan Hukum Islam terhadap Tradisi Hiburan dalam Pesta Perkawinan (Walimah al-'Urs) di Kecamatan Bontomarannu Kabupaten Gowa. Universitas Islam Negeri Alauddin Makassar.

Herningsih, H. (2018). Kebijakan Pemerintah Papua dalam Pelestarian Tradisi Bakar Batu. Millati: Journal of Islamic Studies and Humanities, 3(2), 209-225. https://doi.org/10.18326/mlt.v3i2.209-226

Hidayat, D., \& Hafiar, H. (2019). Nilai-nilai budaya soméah pada perilaku komunikasi masyarakat Suku Sunda. Jurnal Kajian Komunikasi, 7(1), 84-96. https://doi.org/10.24198/jkk.v7i1.19595

Hidayat, D., Kuswarno, E., Zubair, F., \& Hafiar, H. (2017). Negosiasi Citra Budaya Masyarakat Multikultural . Jurnal ASPIKOM, 3(2), 157-172.

Hindaryatiningsih, N. H. (2017). Model Proses Pewarisan Nilai-Nilai Budaya Lokal dalam Tradisi Masyarakat Buton. Sosiohumaniora, 18(2), 100-107. https://doi.org/10.24198/sosiohumaniora.v18i2.9228

Hudha, M. (2020). Wajah Sufisme Antroposentris Kepustakaan Islam Kejawen dalam Pandangan Simuh. Living Islam: Journal of Islamic Discourses, 3(1), 189-208. https://doi.org/10.14421/lijid.v3i1.2161

Jamali, L. L., Zain, L., \& Hasyim, A. F. (2016). Hikmah Walimah Al-`Ursy (Pesta Pernikahan) Dengan Kehormatan Perempuan Perspektif Hadits. Diya Al-Afkar: Jurnal Studi al-Quran Dan al-Hadis, 4(2), $165-182$. https://doi.org/10.24235/DIYAAFKAR.V4I02.1161

Jati, R. (2013). Kearifan Lokal sebagai Resolusi Konflik Keagamaan. Walisongo: Jurnal Penelitian Sosial Keagamaan, 21(2), 393-416. https://doi.org/10.21580/WS.21.2.251

Kholil, A. (2010). Seblang Dan Kenduri Masyarakat Desa Olehsari: Relasi Ideal Antara Islam Dan Budaya Jawa Di Banyuwangi. El-HARAKAH, 12(2), 23721. https://doi.org/10.18860/el.v0i0.447

Krismoniansyah, R., Warsah, I., Jaya, G. P., \& Abdu, M. (2020). Nilai-Nilai Pendidikan Islam Dalam Tradisi Suroan: Studi di Desa IV Suku Menanti, Sindang Dataran Kabupaten Rejang Lebong. At-Ta'dib: Jurnal Ilmiah Prodi Pendidikan Agama Islam, 12(1), 1-14. https://doi.org/10.47498/tadib.v12i01.335

Krutzen, M., Mann, J., Heithaus, M. R., Connor, R. C., Bejder, L., \& Sherwin, W. B. (2005). Cultural transmission of tool use in bottlenose dolphins. Proceedings of the National Academy of Sciences, 102(25), 8939-8943. https://doi.org/10.1073/pnas.0500232102

Lestari, P. D. (2019). Toleransi dalam Keragaman: Studi Kasus Masyarakat Desa Gatak, Jawa Tengah. Muảșarah: Jurnal Kajian Islam Kontemporer, 1(1), 44-52.

Liliweri, A. (2005). Prasangka dan Konflik; Komunikasi Lintas Budaya Masyarakat Multikultur. Yogyakarta: LKiS Pelangi Aksara.

Lubis, H. R. (2017). Sosiologi Agama: Memahami Perkembangan Agama dalam Interaksi Islam. Jakarta: Kencana.

Mahfudin, A., \& Mafthuchin, M. A. (2020). Tradisi Hiburan Dangdut dalam Walimatul 'Ursy. Jurnal Hukum Keluarga Islam, 5(1), 62-78.

Marpi, Y. (2020). Keabsahan Hukum Pernikahan tanpa Adanya Walimatul Ursy di Masa Kahar Pandemi Covid19. As-Syar'i : Jurnal Bimbingan \& Konseling Keluarga, 2(2), 183-194. https://doi.org/10.47467/as.v2i2.130

Maulidiyah, N. (2019). Tradisi Walimatul Ursy Di Desa Panaongan Kecamatan Pasongsongan Kabupaten Sumenep (Analisa Semiotika Komunikasi Dakwah. Maddah, 1(1), 16-28.

Miles, M. B., Huberman, A. M., \& Saldana, J. (2014). Qualitative data analysis: A methods sourcebook. Thousand Oaks, California 91320: SAGE Publications, Inc.

Mudzhar, M. A. (2017). Pendidikan Agama Berwawasan Multikultural. Edukasi: Jurnal Penelitian Pendidikan Agama dan Keagamaan, 4(1), 5-8. https://doi.org/10.32729/edukasi.v4i1.396

Muqoyyidin, A. W. (2013). Membangun kesadaran inklusif multikultural untuk deradikalisasi pendidikan Islam. Jurnal Pendidikan Islam, 2(1), 131-151. https://doi.org/10.14421/jpi.2013.21.131-151

Naim, N. (2017). Abdurrahman Wahid: Universalisme Islam dan Toleransi. KALAM, 10(2), $423-444$. https://doi.org/10.24042/klm.v10i2.8

Nisvilyah, L. (2013). Toleransi Antarumat Beragama dalam Memperkokoh Persatuan dan Kesatuan Bangsa (Studi Kasus Umat Islam dan Kristen Dusun Segaran Kecamatan Dlanggu Kabupaten Mojokerto). Kajian Moral dan Kewarganegaraan, 2(1), 382-396.

Nuh, Z. M., \& Dardiri, D. (2017). Etnomatematika Dalam Sistem Pembilangan Pada Masyarakat Melayu Riau. Kutubkhanah, 19(2), 220-238.

Nurdin, A. F. (2017). Integralisme Islam Dan Budaya Lokal Relevansi Nilai-Nilai Filosofis Budaya Lampung Bagi Pembangunan Daerah. Jurnal Cakrawala Hukum, 6(2), 55-76.

Nurhayati, I., \& Agustina, L. (2020). Masyarakat Multikultural: Konsepsi, Ciri dan Faktor Pembentuknya. Akademika, 14(1), 17-26. https://doi.org/10.30736/adk.v14i01.184

Panjaitan, H. (2014). Pentingnya Menghargai Orang Lain. Humaniora Binus, 5(1), 88-96.

Panjaitan, S. C., \& Dewantara, A. (2019). Gotong Royong sebagai Prinsip Masyarakat Indonesia untuk Menanggapi Konflik Multikulturalisme. OSF Preprints. https://doi.org/10.31219/osf.io/wqd5v

Permana, A., Kusdiana, A., \& Mawardi, H. (2021). Jaringan Habâib di Pulau Jawa Abad 20 (Studi Integrasi Islam dan 
Budaya Lokal dalam Bingkai Islam Nusantara). Bahasa dan Sastra Arab, UIN Sunan Gunung Djati.

Pitoyo, A. J., \& Triwahyudi, H. (2018). Dinamika Perkembangan Etnis di Indonesia dalam Konteks Persatuan Negara. Populasi, 25(1), 64-81. https://doi.org/10.22146/jp.32416

Purnama, F., \& Nurman, N. (2018). Tradisi Pacu Itiak dalam Melestarikan Nilai-Nilai Budaya di Payakumbuh. Journal of Civic Education, 1(2), 174-180. https://doi.org/10.24036/jce.v1i2.183

Rahmawati, R. (2019). Pengembangan Sdm Melalui Program Capacity Building Remaja Di Sanggar Kalpika: Merawat Tradisi Melestarikan Batik Lukis. Jurnal Pemberdayaan Masyarakat: Media Pemikiran dan Dakwah Pembangunan, 2(2), 339-356. https://doi.org/10.14421/jpm.2018.022-07

Roulston, K. (2014). Analysing interviews: The SAGE Handbook of Qualitative Data Analysis. Thousand Oak, CA: Sage Publications.

Santosa, T. A., Agustina, N., \& Yulianti, S. (2020). Jenis Tumbuhan Liar Dalam Upacara Adat Kenduri Seko Di Kerinci. Pendekar : Jurnal Pendidikan Berkarakter, 3(1), 6-10. https://doi.org/10.31764

Sukarniti, N. L. K. (2020). Pewarisan Nilai-Nilai Kearifan Lokal Untuk Memproteksi Masyarakat Bali Dari Dampak Kemajuan Teknologi. Jurnal Ilmiah Cakrawarti, 3(1), 39-50. https://doi.org/10.47532/jic.v3i1.135

Suparlan, P. (2014). Masyarakat Majemuk dan Perawatannya. Antropologi Indonesia, 24(63), 42-50. https://doi.org/10.7454/ai.v0i63.3397

Susanti, R. D. (2017). Tradisi Kenduri Dalam Masyarakat Jawa Pada Perayaan Hari Raya Galungan di Desa Purwosari Kecamatan Tegaldlimo Kabupaten Banyuwangi (Kajian Teologi Hindu). Jurnal Penelitian Agama Hindu, 1(2), 489-495.

Tago, M. Z., \& Shonhaji, S. (2017). Agama dan Integrasi Sosial dalam Pemikiran Clifford Geertz. Kalam, 7(1), 7994.

Utami, N. M. S. N., Sanjiwani, S., Widiastuti, A., Pradnyadani, R., \& Paramitha, R. P. (2018). Hubungan Rasa Syukur Dengan Resiliensi Pengungsi Gunung Agung Di Kabupaten Karangasem, Bali. Prosiding Seminar Nasional dan Call For Paper Peranan Psikologi Bencana Dalam Mengurangi Risiko Bencana, 106-111.

Waridah, E. (2017). Kamus Bahasa Indonesia. Jakarta: Bmedia.

Warsah, I., Cahyani, D., \& Pratiwi, R. (2019). Islamic Integration and Tolerance in Community Behaviour; Multiculturalism Model in The Rejang Lebong District. Khatulistiwa, 9(1), 15-29. https://doi.org/10.24260/khatulistiwa.v9i1.1269

Warsah, Idi. (2017). Kesadaran Multikultural sebagai Ranah Kurikulum Pendidikan. Ta'dib: Jurnal Pendidikan Islam, 6(2), 29-38. https://doi.org/10.29313/tjpi.v6i2.2845

Warsah, Idi. (2018). Pendidikan Keluarga Muslim Di Tengah Masyarakat Multi Agama: Antara Sikap Keagamaan Dan Toleransi (Studi Di Desa Suro Bali Kepahiang-Bengkulu). Edukasia: Jurnal Penelitian Pendidikan Islam, 13(1), 1-24. https://doi.org/10.21043/edukasia.v13i1.2784

Warsah, Idi, Avisa, A., \& Anrial, A. (2020). Pola Komunikasi Antar Umat Beragama Masyarakat Desa Sindang Jaya, Rejang Lebong, Bengkulu. Ar-Risalah: Media Keislaman, Pendidikan dan Hukum Islam, 18(2), $283-307$. https://doi.org/10.29062/arrisalah.v18i2.395

Warsah, Idi, Masduki, Y., Imron, Daheri, M., \& Morganna, R. (2019). Muslim minority in Yogyakarta: Between social relationship and religious motivation. Qudus International Journal of Islamic Studies, 7(2), 367-398. https://doi.org/10.21043/qijis.v7i2.6873

Wibisono, S. (2015). Psikologi Keberagaman: Memahami Dimensi Psikologis dalam Penghayatan Agama. Psikologika, 20(1), 63-77.

Widawati, S. R., Muzaiyana, F., \& Ferian, F. (2018). Nilai-Nilai Gotong Royong Dalam Pernikahan Masyarakat Jawa Di Kadisobo, Trimulyo, Sleman, DIY. Jurnal Ilmiah Penalaran dan Penelitian Mahasiswa, 2(2), 97-110.

Widyastuti, S. (2010). Peribahasa: Cerminan Kepribadian Budaya Lokal dan Penerapannya di Masa Kini. Proceeding of National Seminar of Yogyakarta University of Technology, 1-10. Yogyakarta University of Technology.

Wijayanti, S., Rahmatika, R., \& Listiyandini, R. A. (2020). Kontribusi Kebersyukuran dalam Peningkatan Kualitas Hidup Kesehatan pada Remaja di Panti Asuhan. Psycho Idea, 18(1), 33-44. https://doi.org/10.30595/psychoidea.v18i1.4123

Yusuf, S. E. (2011). Review 5 Tahun Kehidupan Umat Beragama di Indonesia: Perspektif MUI. Kongres FKUB. Jakarta. and conditions of the Creative Commons Attribution (CC BY SA) license (https://creativecommons.org/licenses/by-sa/3.0/). 